Hypsipetes. The whole system of coloration is different from that of the latter genus.

Mr. Leadbeater exhibited a stuffed specimen of a Lesser Bird of Paradise from the collection of Lord Braybrooke, and stated that this individual had been formerly alive in England, at Windsor Castle, in the possession of the late Princess Augusta.

\title{
May 27, 1862.
}

Professor Huxley, F.R.S., V.P., in the Chair.

Mr. T. W. Wood made some remarks on the peculiarities of the habits of the Pinnated Grouse (Tetrao cupido), as displayed by the individuals of this species now living in the Society's Gardens, and exhibited some drawings of the male bird in the attitude assumed whilst setting his feathers.

The following papers were read :-

\section{Narrative of Search after Birds of Paradise. By Alfred R. Wallace, F.Z.S.}

Having visited most of the islands inhabited by the Paradisea, in the hope of obtaining good specimens of those extraordinary birds, and some knowledge of their habits and distribution, I have thought that an outline of my several voyages, with the causes that have led to their only partial success, might not prove uninteresting.

At the close of the year 1856, being then at Macassar in the island of Celebes, I was introduced to the master of a prau trading to the Aru Islands, who assured me that two sorts of Birds of Paradise were abundant there, the large yellow and the small red kinds-the Paradisece apoda and regia of naturalists.

He seemed to think there was no doubt but I could obtain them either by purchase from the natives or by shooting them myself. Thus encouraged, I agreed with him for a passage there and back (his stay being six months), and made all my preparations to start by the middle of December.

Our vessel was a Malay prau of about 100 tons burthen, but differing widely from anything to be seen in European waters. The deck sloped downwards towards the bows, the two rudders were hung by rattans and ropes on the quarters, the masts were triangles standing on the decks, and the huge mat sail, considerably longer than the vessel, with its yard of bamboos, rose upwards at a great angle, so as to make up for the lowness of the mast. In this strange vessel, which, under very favourable circumstances, plunged along at nearly 


\section{$2 \mathrm{BHL}$ Biodiversity Heritage Library}

Huxley, Thomas Henry. 1862. "May 27, 1862." Proceedings of the Zoological Society of London 1862, 153-153.

https://doi.org/10.1111/j.1469-7998.1862.tb06486.x.

View This Item Online: https://www.biodiversitylibrary.org/item/98527

DOI: https://doi.org/10.1111/j.1469-7998.1862.tb06486.x

Permalink: https://www.biodiversitylibrary.org/partpdf/74035

\section{Holding Institution}

Smithsonian Libraries

\section{Sponsored by}

Biodiversity Heritage Library

\section{Copyright \& Reuse}

Copyright Status: Public domain. The BHL considers that this work is no longer under copyright protection.

This document was created from content at the Biodiversity Heritage Library, the world's largest open access digital library for biodiversity literature and archives. Visit BHL at https://www.biodiversitylibrary.org. 